\title{
Stocks Investment Decision Making Capital Asset Pricing Model (CAPM)
}

\author{
Erric Wijaya and Alecia Ferrari \\ Management Department, Indonesia Banking School \\ Email: erric.wijaya@ibs.ac.id
}

\begin{abstract}
Investment in the capital market generally has a higher rate of return compared to investing in the financial market. Investors sometimes get difficulty in determining which stocks will produce a large return with a small risk. The method used to describe the application of CAPM in this research is done by grouping the efficient, yet inefficient stocks of the banking sector based on the CAPM method. The method in the sample selection was a purposive sample method and obtained 40 banking sector companies listed on the Indonesia Stock Exchange (IDX) during the period of August 2016 - July 2018. The results of this study indicate that there are 31 efficient stocks out of 40 stocks in banking sector. It can be seen that there are 31 banking stocks with a positive average rate of returns and 9 banking stocks with a negative average rate of returns. Meanwhile, the implication of this study is that banking sector shares have efficient shares, since the average rate of return is higher than the expected returns.
\end{abstract}

Keywords: CAPM, Beta, Return.

Abstrak: Investasi di pasar modal umumnya memiliki tingkat pengembalian yang lebih tinggi dibandingkan dengan investasi di pasar uang. Investor terkadang kesulitan menentukan saham mana yang akan menghasilkan return yang besar dengan risiko yang kecil. Mendeskripsikan penerapan CAPM dengan cara mengelompokan saham-saham sektor perbankan yang efisien dan tidak efisien berdasarkan metode CAPM. Metode dalam pemilihan sample adalah purposive sample method dan menghasilkan 40 perusahaan sektor perbankan terdaftar di Bursa Efek Indonesia. Populasi dari penelitian ini adalah saham sektor perbankan periode Agustus 2016 - Juli 2018. Hasil penelitian ini menunjukkan bahwa terdapat 31 saham efisien dari 40 saham sektor perbankan. Dapat diketahui bahwa terdapat 31 saham perbankan dengan tingkat pengembalian rata-rata positif dan 9 saham perbankan dengan tingkat pengembalian rata-rata negatif. Implikasi penelitian ini bahwa saham sektor perbankan memiliki saham yang efisien, karena ratarata tingkat pengembalian lebih tinggi dibandingkan dengan pengembalian yang diharapkan.

Kata Kunci: CAPM, Beta, Return.

\section{INTRODUCTION}

Investment is one of the places that many people are interested in getting fund in the future. Moreover, investment is a commitment of funds or other resources made at the 
moment, aiming of obtaining a number of benefits in the future (Tandelilin, 2010). An investor's accuracy in finding information and processing information is very necessary because it will be used as a decision-making tool for investing that will determine how much profit will be gained in the future (Putra, 2013). Rapidly growing investment is not released from the risk, therefore potential investor should be capable of their insight, explore information or see investments that will be profitable in the future. Investment activity can be differentiated into two forms, that is investment in real asset and investment in financial asset. Real asset investment is investment in the form of physical tangible asset, while financial investments are investments in the form of securities/ securities which is conducted in money market and capital market. The form of financial investments in the money market can be described as certificates of deposit and money market securities, meanwhile financial investments in the capital market can be in the form of bonds, warrants, mutual funds, options, futures, and stocks (Yulianti, 2014).

Capital market is the market for long-term securities such as bonds and stocks (Jones, 2013). Capital market is one of investments which is interested by investors and have a big role for Indonesian economy (Yadnya, 2016). With the existence of capital market, companies who need funds to operate and develop their business could get their funds from the securities trade, while for investors have excess of funds could investments in that companies to get profit (Qamar et al., 2014). Capital markets can provide a positive role for companies, investors and the government. For investors, the capital market can help determine the best investment choices that will benefit investors. For the government, aside from being an alternative source of financing, the capital market can also function as a mechanism for capital allocation and corporate monitoring, as well as a means to carry out a market economy in addition to utilizing both fiscal and monetary policies (Seftyanda et al., 2014).

One of the most popular securities instruments in capital market is stocks. Sometimes investors get difficulty to determine which stocks is worthy to buy. The method being used in this research is Capital Asset Pricing Model (CAPM) which is to see the relevant returns and risks, and to find an expected return on the asset if the capital market is equal (Tandelilin, 2010). CAPM relates the required rate of return for any security with the risk for that securities as measured by beta. CAPM can calculate risk in a portfolio (Sekarwati, 2016). CAPM has 2 main advantages to calculate the capital costs of companies related to stocks (Keown et al., 2017): (1) The model is simple and easy to understand and implement. The variables model is available from public sources. (2) Because the model does not depend on dividends or any assumptions about growth in dividends. An efficient market is a market where all prices of traded securities reflect all available information. The information can be in the form of a company's earnings report, dividend distribution, stock split, as well as reports from capital market analysts (Nasution, 2015).

Information on stock market performance can be seen on the Indonesia Stock Exchange. Stocks Listed on Indonesia Stock Exchange are differentiated into nine sectors. This research was conducted in one of the financial sectors, which is banking sector. This research was conducted from August 2016 - July 2018. This research began in August 2016 because there was a change in the BI Rate to the BI 7 Day Repo Rate during the process of period. Various circles assess the prospect of 2018 banking sector stocks will be better than the previous year. Since July 2016 to July 2018, the banking sector is the sector 
that has the biggest market capitalization in Indonesia.

Figure 1. Market Capitalization August 2016 - July 2018

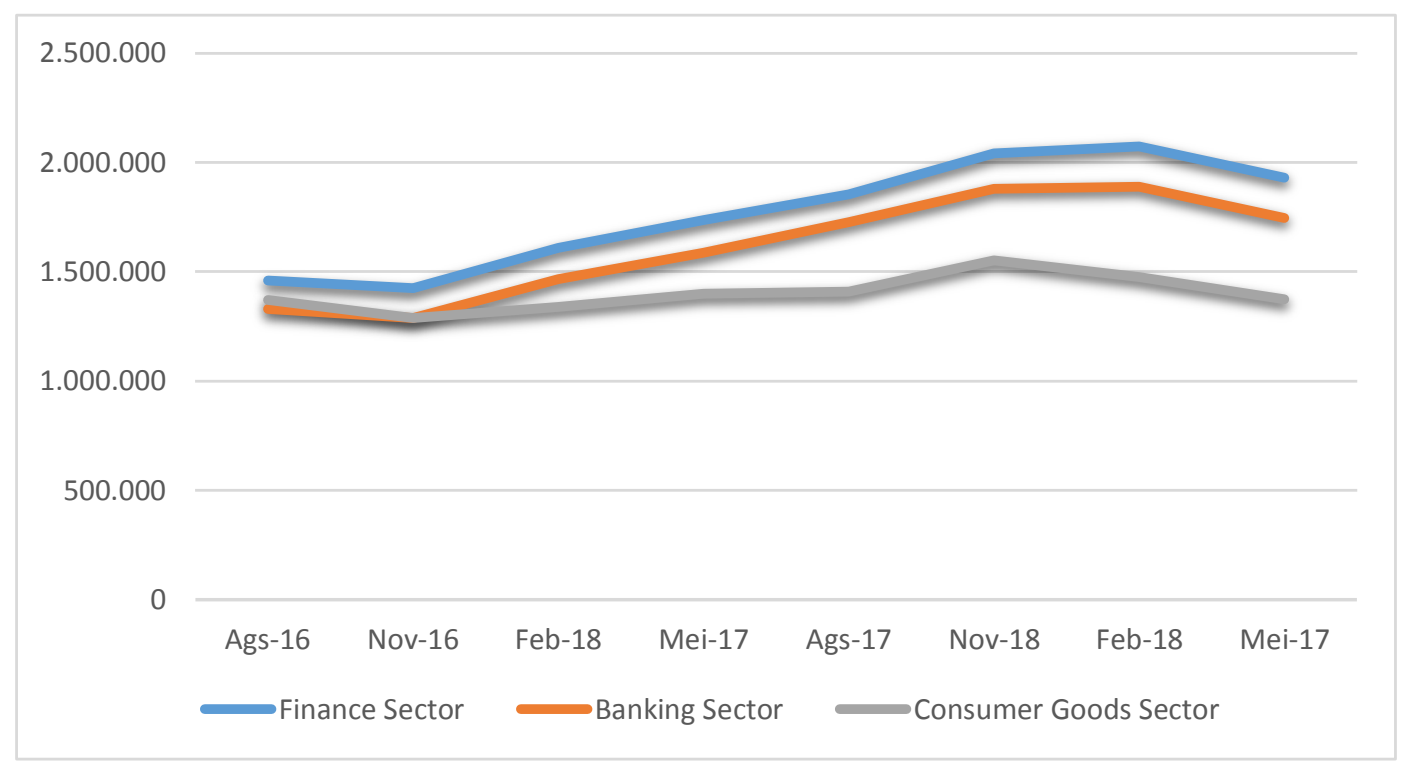

Source: (IDX, processed by the author, 2018)

Based on the graph above, it can be seen that the market capitalization of the banking sector is the biggest market capitalization in the financial sector. The financial sector is also the biggest market capitalization because the banking sector is the primary mover in Jakarta Composite Index. The banking sector is one of sector that is vital for a state. There are many sources of bank funds collected from wide community. The source of the funds used for business development through credit or loans.

Research Problems: (1) What is the return and risk of each banking sector stocks? (2) What is the expected rate of return of each stock in the banking sector ? (3) How is the grouping and valuation of efficient and inefficient banking sector stocks based on the Capital Asset Pricing Model (CAPM) method?

\section{THEORETICAL REVIEW}

Efficient Market Hypotesis. This hypothesis states that securities prices accurately reflect the future expected cash flows and are based on all information available to investors (Keown et al., 2017). While, Efficient Market state that all important information stocks is reflected in the stock price (Eugene F, 2017).

Weak Form Efficient Market Hypothesis. Suggests that all past information is priced into securities. Fundamental analysis of securities can provide an investor with information to produce returns above market averages in the short term but there are no "patterns" that exist. Therefore, fundamental analysis does not provide long-term advantage and technical analysis will not work (Bodie and Marcus, 2018). 
Semi-Strong Form Efficient Market Hypothesis. Implies that neither fundamental analysis nor technical analysis can provide an advantage for an investor and that new information is instantly priced in to securities (Bodie and Marcus, 2018).

Strong Form Efficient Market Hypothesis. Says that all information, both public and private, is priced into stocks and that no investor can gain advantage over the market as a whole. Strong Form EMH does not say some investors or money managers are incapable of capturing abnormally high returns but that there are always outliers included in the averages (Bodie and Marcus, 2018). Capital Asset Pricing Model (CAPM) which is to see the relevant returns and risks, and to find an expected return on the asset if the capital market is equal (Tandelilin, 2010). CAPM an equation stating that the expected rate of return on an investment is a function of the expected risk premium for the market portfolio of all risky securities. The Capital Asset Pricing Model (CAPM) is one of the asset pricing models that was first applied in securities valuation. CAPM has a lot of criticism, both empirically and theoretically. However, with its intuitive appeal and simplicity, it has made CAPM a useful tool used in practice (Shaikh, 2013). In addition, CAPM has been criticized for assuming investors only care about market risk and return on portfolio assets, meanwhile beta can still explain expected results, with market portfolios being a proxy of all risk assets. Therefore, CAPM remains in use and many industries rely on this model to determine their market prices (Elbannan, 2015)

\section{CAPM formula:}

$$
\mathrm{E}(R i)=R_{f}+\beta \mathrm{i}\left[\mathrm{E}\left(R_{m}\right)-R_{f}\right]
$$

Source: (Tandelilin, 2010)

$\mathrm{E}(\mathrm{Ri}) \quad=$ The expected rate of return on securities $\mathrm{i}$.

$\mathrm{E}(\mathrm{Rm})=$ The rate of return on the average market.

$\mathrm{Rf}=$ Average risk-free return on investment.

$\beta \mathrm{i}=$ The measure of the risk of stock $\mathrm{i}$.

BETA. Beta is the relationship between an investment's returns and the market's returns. This is a measure of the investment's non-diversiable risk. The meaning of the systematic risk of a particular stock (Jones, 2013): (1) Beta <0, is negative, that means stocks behave specifically and contradictory with the capital market. When the market goes up, these types of stocks actually move down, and when the market moves down, these stocks actually move up. (2) Beta $=1$, that means every one percent change in market return, the stock return or portfolio will also change as large as the market return. (3) Beta $>1$, that means the risk is over than the level of the average market risk. (4) Beta $<1$, that means the stocks have a below risk than the level of the average market risk. In addition, beta can also be called a systematic risk gauge of a security or portfolio relative to market risk (Akram, 2017).

Source: (Bodie and Marcus, 2018)

$$
\beta \mathrm{i}=\frac{\operatorname{cov}\left(r_{i}, r_{m}\right)}{\operatorname{var}\left(r_{m}\right)}
$$


Stock Returns. The rate of return is one of the factors that motivates investors to interact and is also a reward for the investor's courage to bear the risks to the investment he made (Tandelilin, 2010).

$$
\text { Stock Return }=\frac{P_{t}-P_{t-1}}{P_{t-1}}
$$

Market Returns. Market returns are the returns that the investors generate out of the stock market (Jogiyanto, 2013).

$$
\text { Market Return }=\frac{{\text { Indeks pasar } \mathrm{t}-\text { Indeks Pasar }_{\mathrm{t}-1}}_{\text {Indeks Pasar }} \mathrm{t}-1}{.}
$$

Risk Free Rate. According to (Husnan, 2015) who explains that the risk-free rate of return is a measure of the minimum rate of return when the risk of beta ( $\beta \mathrm{i})$ is zero. Risk free rate is the theoretical rate of return of an investment with zero risk. The risk-free rate of return is represented by the BI 7 Days Repo Rate set by Bank Indonesia.

$$
R f=\frac{\sum \mathrm{Rf}}{N}
$$

Source: (Jogiyanto, 2013). 


\section{Framework}

Figure 2. Conceptual framework

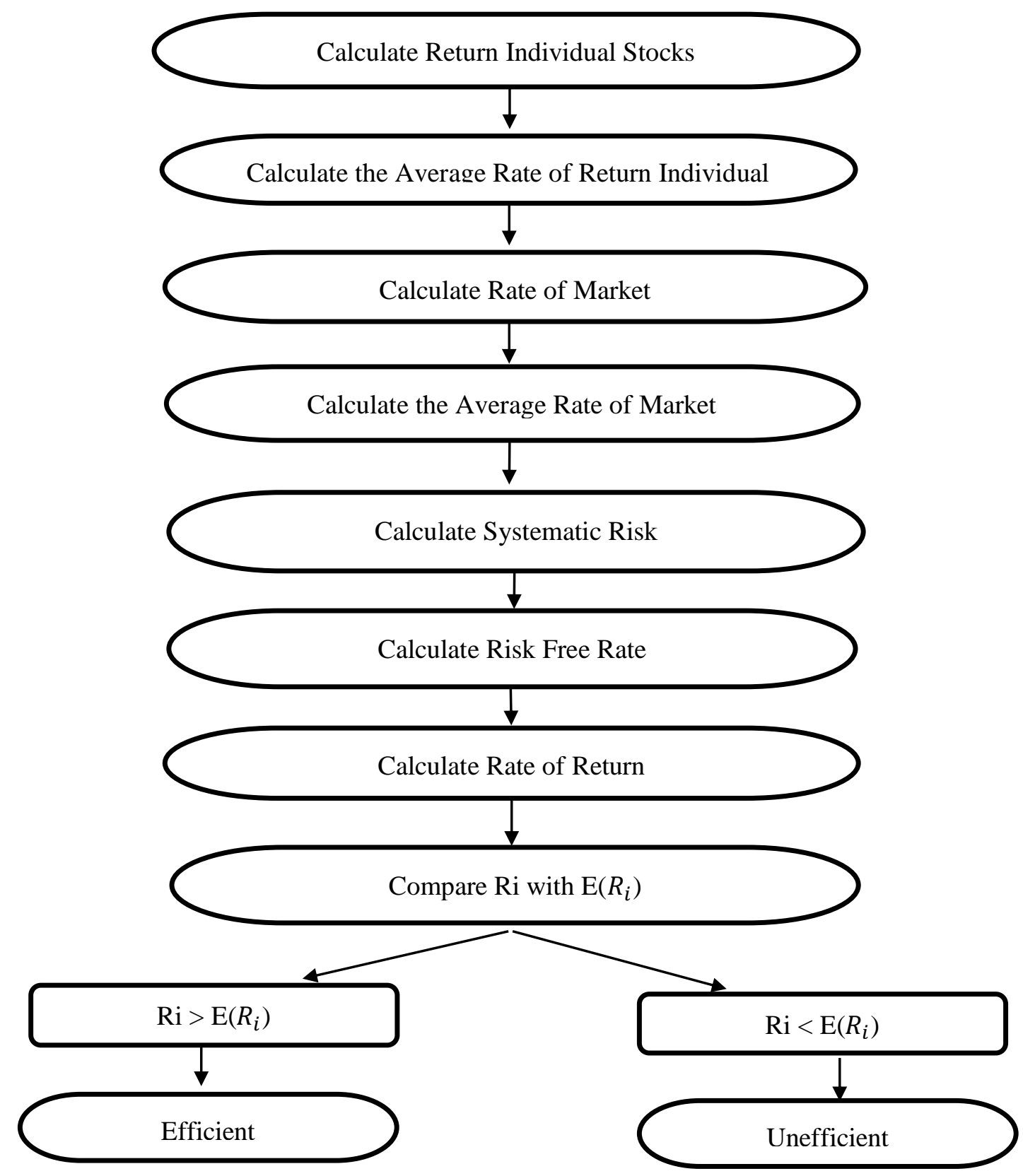

Source: (Processed by the author, 2018)

\section{METHODOLOGY}

Population and Sample. The population used as the object in this research is the Banking Sector company for the period of August 2016-July 2018. Banking sector is a sector that collects funds (funding) and channel funds (lending) (Kasmir, 2014). The sampling phase used in this research uses purposive sampling, sampling based on certain criteria. The 
criteria are as follows: (1) Banking sector companies listed on the Indonesia Stock Exchange during the period August 2016 - July 2018. (2) Banking sector companies that have never been delisted on the Indonesia Stock Exchange during the period of August 2016 - July 2018. (3) Banking sector companies that have active trading on the Indonesia Stock Exchange during the period of August 2016 - July 2018. Based on the sample criteria, the number of samples in this research were 40 companies out of 42 companies in the banking sector on the IDX.

Data Source. The data used in this research is secondary data in the form of monthly data from banking sector companies issued by the Indonesia Stock Exchange. The research period starts from August 2016 - July 2018. Data sources can be obtained through the website www.idx.co.id.

Research Method. The method being used in this research is Capital Asset Pricing Model (CAPM) which is to see the relevant returns and risks, and to find an expected return on the asset if the capital market is equal. This research is a type of quantitative data, data can be measured using a numerical scale. The source of data used in this research is use secondary data banking stock prices closing price per month during the period August 2016 - July 2018, Jakarta Composite Index, and BI Rate. Other supporting sources in the form of journals are needed, and other sources that can be used in this research. The formula of the CAPM is as follows:

Operational Variable. Operational variable is a way to describe the research variables of a concept and to facilitate understanding and avoid discrepancy in perception of research.

Table 1. Operational Variable

\begin{tabular}{c|c|c|c|c}
\hline No & Variable & $\begin{array}{c}\text { Operational } \\
\text { Definition }\end{array}$ & Equation & $\begin{array}{c}\text { Scale of } \\
\text { Statistic }\end{array}$ \\
\hline 1 & $\begin{array}{c}\text { Return } \\
\text { Market } \\
(\mathrm{Rm})\end{array}$ & $\begin{array}{c}\text { Returns that investors } \\
\text { get from investing in } \\
\text { shares that are } \\
\text { reflected in changes } \\
\text { in price index for a } \\
\text { certain period. }\end{array}$ & Rmt $^{\text {Market Index }} \mathrm{t}$ & Ratio \\
\hline 2 & $\begin{array}{c}\text { Market Index } \mathrm{t}-1 \\
\text { Market } \\
\text { Return }\end{array}$ & $\begin{array}{c}\text { Sogiyanto, 2013) } \\
\text { return of the capital } \\
\text { market within a } \\
\text { certain time period } \\
\text { obtained from certain } \\
\text { model, namely the } \\
\text { Composite Stock } \\
\text { Price Index (CSPI) }\end{array}$ & E(Rm) $=\frac{\sum_{i=1}^{N} R m t}{N}$ & Ratio \\
\hline 3 & $\begin{array}{c}\text { Risk Free } \\
\text { Rate (Rf) }\end{array}$ & $\begin{array}{c}\text { The risk-free rate of } \\
\text { return in this study is } \\
\text { the average BI 7 }\end{array}$ & Rf $=\frac{\sum \mathrm{Rf}}{N}$ & Ratio \\
\hline
\end{tabular}




\begin{tabular}{|c|c|c|c|c|}
\hline No & Variable & $\begin{array}{c}\text { Operational } \\
\text { Definition }\end{array}$ & Equation & $\begin{array}{l}\text { Scale of } \\
\text { Statistic }\end{array}$ \\
\hline & & $\begin{array}{l}\text { Days Repo Rate set } \\
\text { by Bank Indonesia. }\end{array}$ & (Jogiyanto, 2013) & \\
\hline 4 & $\operatorname{Beta}(\beta)$ & $\begin{array}{l}\text { Beta is a measure of } \\
\text { volatility return of a } \\
\text { security or portfolio } \\
\text { return to market } \\
\text { returns. }\end{array}$ & $\begin{array}{c}\beta \mathrm{i}=\frac{\operatorname{cov}\left(r_{i}, r_{m}\right)}{\operatorname{var}\left(r_{m}\right)} \\
\text { Source: } \\
\text { (Bodie and Marcus, } \\
\text { 2018) }\end{array}$ & Ratio \\
\hline 5 & $\begin{array}{l}\text { Stock } \\
\text { Return } \\
(\mathrm{Ri})\end{array}$ & $\begin{array}{l}\text { The rate of return } \\
\text { obtained from the } \\
\text { investment of a } \\
\text { number of funds in a } \\
\text { stock investment. }\end{array}$ & $\begin{array}{c}\mathrm{Rt}=\frac{P_{t}-P_{t-1}}{P_{t-1}} \\
\text { Source: } \\
\text { (Tandelilin, 2010) }\end{array}$ & Ratio \\
\hline 6 & $\begin{array}{l}\text { Stock } \\
\text { Expected } \\
\text { Return } \\
\mathrm{E}\left(R_{i}\right)\end{array}$ & $\begin{array}{l}\text { The average rate of } \\
\text { return of individual } \\
\text { shares in the selected } \\
\text { period. }\end{array}$ & $\begin{array}{c}\mathrm{E}(\mathrm{Ri})= \\
\mathrm{R} f+\left[\mathrm{E}\left(R_{m}\right)-R_{f}\right] B_{i} \\
\text { Source: } \\
(\text { Tandelilin, 2010) }\end{array}$ & Ratio \\
\hline
\end{tabular}

Source: (Processed by the author, 2018)

\section{CAPM Formulation:}

$$
\mathrm{E}(R i)=R_{f}+\beta \mathrm{i}\left[\mathrm{E}\left(R_{m}\right)-R_{f}\right]
$$

Source: (Tandelilin, 2010)

$\mathrm{E}(\mathrm{Ri}) \quad=$ The expected rate of return on securities $\mathrm{i}$.

$\mathrm{E}(\mathrm{Rm})=$ The rate of return on the average market.

Rf = Average risk-free return on investment.

$\beta \mathrm{i}=$ The measure of the risk of stock $\mathrm{i}$.

Stock classifications as investment decisions:

$\mathrm{Ri}>\mathrm{E}(\mathrm{Ri})$ then the shares are efficient shares.

$\mathrm{Ri}<\mathrm{E}(\mathrm{Ri})$ then the stock is an inefficient stock. 


\section{ANALYSIS AND DISCUSSION}

\section{DESCRIPTIVE ANALYSIS}

Table 2. Descriptive Analysis

\begin{tabular}{c|c|c|c|c|c}
\hline & $\begin{array}{c}\text { BI 7 Days } \\
\text { Repo Rate }\end{array}$ & IHSG & RI & Beta & CAPM \\
\hline Mean & 0,0465 & 5774,49 & 0,02126 & 0,8030 & 0,0056 \\
\hline Median & 0,0475 & 5829,71 & 0,01475 & 0,8584 & 0,00485 \\
\hline Maximum & 0,0525 & 6605,63 & 0,1286 & 3.9804 & 0,0115 \\
\hline Minimum & 0,0425 & 5148,91 & $-0,0231$ & $-2,0213$ & 0,0001 \\
\hline Std Deviation & 0,003372 & 395,3531 & 0,029755 & 1,199805 & 0,002288 \\
\hline
\end{tabular}

Source: (Output Data EViews, 2018)

In the following explanation is based on the data of each variable based on a model that has been processed. Descriptive statistics provide a description by displaying a histogram (describing the frequency distribution of data) and some basic statistical calculations, such as average, maximum, minimum, etc. (Winarno, 2017). Based on the information described in the table, can be described on the explanation of each variable descriptive statistics research, namely:

BI 7-Day (Reverse) Repo Rate. Based on data processing performed using EViews 10 software, the BI 7-Day (Reverse) Repo Rate has an average of 0.0465 or $4.65 \%$. While the lowest value is 0.0425 or $4.25 \%$ it occurs in September 2017 to April 2018 due to low inflation in the month (marketbisnis.com). The highest value is 0.0525 or $5.25 \%$ because BI maintains the competitiveness of the domestic financial market against changes in monetary policy of a number of countries and the uncertainty of the global financial market is still high. (BI.go.id).

Jakarta Composite Index. The JCI has an average of 5774.49. The lowest value was 5148.91 occurred in October 2016, this was due to profit taking while waiting for China's economic growth figures. While the highest value of 6605.63 occurred in January 2018 due to the economic conditions in Indonesia tend to be stable and stagnant throughout 2017 (marketbisnis.com).

Average Stock Returns. The average rate of return of stocks has an average of 0.02126 or $2.13 \%$. This shows that the average rate of return of stocks provides an average profit of $2.13 \%$ during the period. The lowest value of the individual stock returns is -0.0231 or $2.31 \%$ in the Bank Maybank Indonesia Tbk company. While the highest value of individual stock returns is 0.1286 or $12.86 \%$ is found in the Bank Ina Perdana Tbk company. This shows that the individual rate of return of Bank Ina Perdana Tbk provides an average profit of $12.86 \%$ during the period of August 2016 - July 2018.

Beta. Beta has an average of 0.8030 . The highest value of beta is 3.9804 at Bank Mitra Niaga (NAGA). Beta of 3.9804 can be interpreted if the market is experiencing an 
increase or decrease of $4 \%$, then NAGA shares will experience an increase of 3.9804 times from 4\%, and will decrease by 3.9804 times from $4 \%$. The lowest value of beta is 2.0213 for the Bank Yudha Bhakti Tbk (BBYB) company.

CAPM. CAPM has an average of 0.0056. The lowest value of the lowest expected Return Rate is 0.0001 or $0.001 \%$ is found in the Bank Yudha Bhakti Tbk (BBYB) company, and the highest value of expected return is 0.0115 or $1.15 \%$ in the Bank Mitra Niaga company (NAGA). This can mean that investors expect a profit rate of $1.15 \%$ for the Bank Mitra Niaga company (NAGA) and expect a profit rate of $0.001 \%$ at the Bank Yudha Bhakti (BBYB) company.

Results of Individual Stock Return Analysis. Individual stock returns is one of the investors in making investment considerations. The calculation of the rate of return of individual stocks in this study using the monthly closing price. The result of the calculation of individual stock returns of 40 banks that the research sample are:

Table 3. Individual Stock Returns

\begin{tabular}{|c|c|c|c|c|c|}
\hline No & Company List & $\mathbf{R i}$ & No & Company List & $\mathbf{R i}$ \\
\hline 1 & Bank Ina Perdana & 0.1286 & 21 & Bank China Construction. & 0.0141 \\
\hline 2 & Bank Agris & 0.1086 & 22 & Bank Rakyat Indonesia (Persero) & 0.0139 \\
\hline 3 & Bank Harda Internasional & 0.059 & 23 & Bank Mandiri (Persero) & 0.013 \\
\hline 4 & Bank Yudha Bhakti & 0.0492 & 24 & Bank Ganesha & 0.0125 \\
\hline 5 & Bank Mayapada International & 0.0464 & 25 & Bank Tabungan Negara (Persero) & 0.0121 \\
\hline 6 & Bank Mitraniaga & 0.046 & 26 & Bank Arto Indonesia & 0.0113 \\
\hline 7 & Bank Victoria International & 0.0439 & 27 & Bank Nusantara Parahyangan & 0.0102 \\
\hline 8 & BPD Banten & 0.0399 & 28 & Bank Maspion Indonesia & 0.0089 \\
\hline 9 & Bank Jabar Banten & 0.0393 & 29 & Bank CIMB Niaga & 0.0087 \\
\hline 10 & Bank Nationalnobu & 0.034 & 30 & BPD Jawa Timur & 0.0076 \\
\hline 11 & Bank Danamon Indonesia & 0.0325 & 31 & Bank Pan Indonesia & 0.0059 \\
\hline 12 & Bank Dinar Indonesia & 0.0313 & 32 & Bank Artha Graha International & -0.0009 \\
\hline 13 & BTPN & 0.0265 & 33 & Bank Mestika Dharma & -0.0021 \\
\hline 14 & Bank Central Asia Tbk & 0.022 & 34 & $\begin{array}{c}\text { Bank Woori Saudara Indonesia } \\
1906 \\
\end{array}$ & -0.0057 \\
\hline 15 & Bank Mega & 0.0206 & 35 & Bank Permata & -0.006 \\
\hline 16 & $\begin{array}{c}\text { Bank Rakyat Indonesia Agro } \\
\text { Niaga }\end{array}$ & 0.0205 & 36 & Bank Sinar Mas & -0.0096 \\
\hline 17 & Bank OCBC NISP & 0.0191 & 37 & Bank Bukopin & -0.0103 \\
\hline 18 & Bank Capital Indonesia & 0.019 & 38 & Bank QNB Indonesia & -0.0136 \\
\hline 19 & Bank Negara Indonesia (Persero) & 0.0168 & 39 & Bank MNC Internasional & -0.0153 \\
\hline 20 & Bank Bumi Arta & 0.0156 & 40 & Bank Maybank Indonesia & -0.0231 \\
\hline
\end{tabular}

Source: (Processed by author, 2018) 
From Table 4 there were 31 banks with an average rate of return is positive. Stock which have an average rate of return positive indicates that the stock is profit for investors during the period of this research. The highest average rate of return of individual stocks is the Bank Ina Perdana Tbk 0.1286 or $12.86 \%$. The average rate of return of $12.86 \%$ stated that, totalling $12.86 \%$ rate of return obtained for investors to invest in the period. There are 9 stocks with negative average returns. The average rate of return on the lowest individual stocks is Bank Maybank Indonesia Tbk -0.0231. or $-2.31 \%$. Stocks with a negative rate of return on stocks that do not get profit or benefit to the investor during the study period.

Results of Individual Systematic Risk Analysis. Beta is a measure of the relevant risk can not be diversified in the portfolio. Beta becomes a measure that investors must consider in the portfolio management decision process. Below is a systematic risk table for each stock:

Table 4. Systematic Risk

\begin{tabular}{|c|c|c|c|c|c|}
\hline No & Company List & $\boldsymbol{\beta}$ & No & Company List & $\boldsymbol{\beta}$ \\
\hline 1 & Bank Mitraniaga & 3.9804 & 21 & Bank Sinar Mas & 0.7620 \\
\hline 2 & Bank Ganesha & 2.5627 & 22 & Bank Nationalnobu & 0.7323 \\
\hline 3 & Bank Harda Internasional & 2.3017 & 23 & $\begin{array}{c}\text { Bank Woori Saudara Indonesia } \\
1906 \\
\end{array}$ & 0.6056 \\
\hline 4 & Bank Bukopin & 2.2204 & 24 & Bank Bumi Arta & 0.5570 \\
\hline 5 & Bank CIMB Niaga & 2.0366 & 25 & Bank Arto Indonesia & 0.5412 \\
\hline 6 & Bank Danamon Indonesia & 2.0278 & 26 & Bank Mestika Dharma & 0.4038 \\
\hline 7 & Bank Negara Indonesia & 2.0093 & 27 & Bank Maspion Indonesia & 0.3424 \\
\hline 8 & Bank Agris & 1.9615 & 28 & Bank Maybank Indonesia & 0.3254 \\
\hline 9 & Bank Jabar Banten & 1.8236 & 29 & Bank Nusantara Parahyangan & 0.3095 \\
\hline 10 & Bank Rakyat Indonesia & 1.6564 & 30 & Bank Victoria International & 0.2833 \\
\hline 11 & Bank Tabungan Negara & 1.5532 & 31 & Bank Permata & 0.2759 \\
\hline 12 & Bank Mandiri & 1.3732 & 32 & Bank Ina Perdana & 0.1789 \\
\hline 13 & Bank Pan Indonesia & 1.2961 & 33 & Bank Capital Indonesia & -0.0175 \\
\hline 14 & Bank Mega & 1.2273 & 34 & Bank MNC Internasional & -0.0546 \\
\hline 15 & Bank Central Asia & 1.1858 & 35 & $\begin{array}{c}\text { Bank Pembangunan Daerah } \\
\text { Banten }\end{array}$ & -0.1237 \\
\hline 16 & $\begin{array}{c}\text { Bank Tabungan Pensiunan } \\
\text { Nasional }\end{array}$ & 1.1316 & 36 & Bank Mayapada International & -0.2513 \\
\hline 17 & BPD Jawa Timur & 0.8396 & 37 & $\begin{array}{c}\text { Bank Rakyat Indonesia Agro } \\
\text { Niaga }\end{array}$ & -0.5778 \\
\hline 18 & $\begin{array}{c}\text { Bank China Construction Bank } \\
\text { Ind }\end{array}$ & 0.8299 & 38 & Bank Artha Graha International & -1.8266 \\
\hline 19 & Bank QNB Indonesia & 0.7878 & 39 & Bank Dinar Indonesia & -1.9275 \\
\hline 20 & Bank OCBC NISP & 0.7875 & 40 & Bank Yudha Bhakti & -2.0123 \\
\hline
\end{tabular}

Source: (Processed by author, 2018) 
Based on table 5 , there are 16 stocks that have $\beta>1$. The highest beta is in the is Bank Mitra Niaga (NAGA), which is 3.9804. Stocks with beta more than 1, it indicates that this stock is aggressive. Based on Table 5 , there are 16 stocks that have $\beta<1$. Beta are positive and less than 1 means that the market Jakarta Composite Index increase, then the stock will go up, but the increase is always lower than the increase in the market. There are 8 stocks that have $\beta<0$. The lowest beta is $-2,0123$, that is the Bank Yudha Bhakti Tbk company. Beta stocks that have a negative and a value of less than 1 , that means stocks behave specifically and contrary with the capital market. When the market goes up, these types of stocks actually move down, and when the market moves down, these stocks actually move up.

Results of the Expected Returns Rate Analysis. The expected rate of return is how much profit investors expect from the stock investment. Below are the expected rate tables:

Table 5. Expected Rate of Return

\begin{tabular}{|c|c|c|c|c|c|}
\hline No & Company List & $\mathbf{E}\left(\boldsymbol{R}_{\boldsymbol{i}}\right)$ & No & Company List & $\mathbf{E}\left(\boldsymbol{R}_{\boldsymbol{i}}\right)$ \\
\hline 1 & Bank Mitraniaga & 0.0115 & 21 & Bank Sinar Mas & 0.0053 \\
\hline 2 & Bank Ganesha & 0.0088 & 22 & Bank Nationalnobu & 0.0053 \\
\hline 3 & Bank Harda Internasional & 0.0083 & 23 & $\begin{array}{l}\text { Bank Woori Saudara Indonesia } \\
1906\end{array}$ & 0.0051 \\
\hline 4 & Bank Bukopin & 0.0081 & 24 & Bank Bumi Arta & 0.0050 \\
\hline 5 & Bank CIMB Niaga & 0.0078 & 25 & Bank Arto Indonesia & 0.0049 \\
\hline 6 & Bank Danamon Indonesia & 0.0078 & 26 & Bank Mestika Dharma & 0.0047 \\
\hline 7 & Bank Artha Graha International & 0.0004 & 27 & Bank Maspion Indonesia & 0.0046 \\
\hline 8 & Bank Agris & 0.0076 & 28 & Bank Maybank Indonesia & 0.0045 \\
\hline 9 & Bank Jabar Banten & 0.0074 & 29 & Bank Nusantara Parahyangan & 0.0045 \\
\hline 10 & Bank Rakyat Indonesia & 0.0070 & 30 & Bank Victoria International & 0.0044 \\
\hline 11 & Bank Tabungan Negara & 0.0069 & 31 & Bank Permata & 0.0044 \\
\hline 12 & Bank Mandiri & 0.0065 & 32 & Bank Ina Perdana & 0.0042 \\
\hline 13 & Bank Pan Indonesia & 0.0064 & 33 & Bank Capital Indonesia & 0.0039 \\
\hline 14 & Bank Mega & 0.0062 & 34 & Bank MNC Internasional & 0.0038 \\
\hline 15 & Bank Central Asia & 0.0062 & 35 & $\begin{array}{c}\text { Bank Pembangunan Daerah } \\
\text { Banten }\end{array}$ & 0.0037 \\
\hline 16 & $\begin{array}{c}\text { Bank Tabungan Pensiunan } \\
\text { Nasional }\end{array}$ & 0.0061 & 36 & Bank Mayapada International & 0.0034 \\
\hline 17 & $\begin{array}{l}\text { Bank Pembangunan Daerah Jawa } \\
\text { Timur }\end{array}$ & 0.0055 & 37 & $\begin{array}{c}\text { Bank Rakyat Indonesia Agro } \\
\text { Niaga }\end{array}$ & 0.0028 \\
\hline 18 & $\begin{array}{l}\text { Bank China Construction Bank } \\
\text { Ind }\end{array}$ & 0.0055 & 38 & Bank Negara Indonesia & 0.0002 \\
\hline 19 & Bank QNB Indonesia & 0.0054 & 39 & Bank Dinar Indonesia & 0.0002 \\
\hline 20 & Bank OCBC NISP & 0.0054 & 40 & Bank Yudha Bhakti & 0.0001 \\
\hline
\end{tabular}

Source: (Processed by author, 2018) 
There are 40 stocks with positive expected returns. With the highest rate of return is 0.0115 or $1.15 \%$, Bank Mitraniaga Tbk (NAGA). The stock of Bank Mitra Niaga Tbk (NAGA) have a positive expected rate of return because NAGA stock has the highest beta. While the lowest rate of return is 0.0001 or equal to $0.01 \%$, of Bank Yudha Bhakti (BBYB). This is in consistent with the CAPM method, because in the CAPM method the relationship between expected returns and the risks of investment has a positive relationship and is directly proportional. It can be concluded that the banking sector shares have a positive expected rate of return in that period.

Efficient Stock Groupings and Investment Decisions. Efficient stocks are stocks with individual returns greater than the expected rate of return [(Ri)> E (Ri)]. While inefficient stock conditions indicate that the individual rate of return $(\mathrm{Ri})$ is smaller than the expected rate of return $[(\mathrm{E}(\mathrm{Ri})]$.

Table 6. Efficient Stocks

\begin{tabular}{|c|c|c|c|c|}
\hline No & Company List & Code & $\mathbf{R i}$ & $\mathbf{E}\left(\boldsymbol{R}_{\boldsymbol{i}}\right)$ \\
\hline 1 & Bank Ina Perdana Tbk & BINA & 0.1286 & 0.0042 \\
\hline 2 & Bank Agris Tbk & AGRS & 0.1086 & 0.0076 \\
\hline 3 & Bank Harda Internasional Tbk & BBHI & 0.059 & 0.0083 \\
\hline 4 & Bank Yudha Bhakti Tbk & BBYB & 0.0492 & 0.0001 \\
\hline 5 & Bank Mayapada International Tbk & MAYA & 0.0464 & 0.0034 \\
\hline 6 & Bank Mitraniaga Tbk & NAGA & 0.046 & 0.0115 \\
\hline 7 & Bank Victoria International Tbk & BVIC & 0.0439 & 0.0044 \\
\hline 8 & Bank Pembangunan Daerah Banten Tbk & BEKS & 0.0399 & 0.0037 \\
\hline 9 & Bank Jabar Banten Tbk & BJBR & 0.0393 & 0.0074 \\
\hline 10 & Bank Nationalnobu Tbk & NOBU & 0.034 & 0.0053 \\
\hline 11 & Bank Danamon Indonesia Tbk & BDMN & 0.0325 & 0.0078 \\
\hline 12 & Bank Dinar Indonesia Tbk & DNAR & 0.0313 & 0.0002 \\
\hline 13 & Bank Tabungan Pensiunan Nasional Tbk & BTPN & 0.0265 & 0.0061 \\
\hline 14 & Bank Central Asia Tbk & $\mathrm{BBCA}$ & 0.022 & 0.0062 \\
\hline 15 & Bank Mega Tbk & MEGA & 0.0206 & 0.0062 \\
\hline 16 & Bank Rakyat Indonesia Agro Niaga Tbk & AGRO & 0.0205 & 0.0028 \\
\hline 17 & Bank OCBC NISP Tbk & NISP & 0.0191 & 0.0054 \\
\hline 18 & Bank Capital Indonesia Tbk & BACA & 0.019 & 0.0039 \\
\hline 19 & Bank Negara Indonesia (Persero) Tbk & BBNI & 0.0168 & 0.0077 \\
\hline 20 & Bank Bumi Arta Tbk & BNBA & 0.0156 & 0.005 \\
\hline 21 & Bank China Construction Bank Ind. Tbk & MCOR & 0.0141 & 0.0055 \\
\hline 22 & Bank Rakyat Indonesia (Persero) Tbk & BBRI & 0.0139 & 0.007 \\
\hline 23 & Bank Mandiri (Persero) Tbk & BMRI & 0.013 & 0.0065 \\
\hline 24 & Bank Ganesha Tbk & BGTG & 0.0125 & 0.0088 \\
\hline
\end{tabular}




\begin{tabular}{l|l|l|l|l}
\hline 25 & Bank Tabungan Negara (Persero) Tbk & BBTN & 0.0121 & 0.0069 \\
\hline 26 & Bank Arto Indonesia Tbk & ARTO & 0.0113 & 0.0049 \\
\hline 27 & Bank Nusantara Parahyangan Tbk & BBNP & 0.0102 & 0.0045 \\
\hline 28 & Bank Maspion Indonesia Tbk & BMAS & 0.0089 & 0.0046 \\
\hline 29 & Bank CIMB Niaga Tbk & BNGA & 0.0087 & 0.0078 \\
\hline 30 & Bank Pembangunan Daerah Jawa Timur Tbk & BJTM & 0.0076 & 0.0055 \\
\hline 31 & Bank Pan Indonesia Tbk & PNBN & 0.0059 & 0.0064 \\
\hline \multicolumn{2}{l}{ Source: (Processed by author, 2018) }
\end{tabular}

Based on table 7 there are 31 efficient shares of 40 banking sector stock research samples. First place stocks, Bank Ina Perdana (BINA) stocks have the biggest difference between $\mathrm{Ri}$ and $\mathrm{E}(\mathrm{Ri})$ that is equal to 0.1244 or $12.44 \%$. Stocks of Bank Ina Perdana capable of providing real profit worth $12.44 \%$ of the returns expected by investors. The criteria in determining investment decisions is choosing efficient stocks, stocks that have the individual return is greater than the expected rate $(\mathrm{Ri}>\mathrm{E}(\mathrm{Ri})$. The investment decision for efficient stock / good that is considering buying the stocks.

Table 7. Inefficient Stocks

\begin{tabular}{c|c|c|c|c}
\hline No & Company List & Code & Ri & $\mathbf{E}\left(\boldsymbol{R}_{\boldsymbol{i}}\right)$ \\
\hline 1 & Bank Artha Graha International Tbk & INPC & -0.0009 & 0.0004 \\
\hline 2 & Bank Mestika Dharma Tbk & BBMD & -0.0021 & 0.0047 \\
\hline 3 & Bank Permata Tbk & BNLI & -0.006 & 0.0044 \\
\hline 4 & Bank Woori Saudara Indonesia 1906 Tbk & SDRA & -0.0057 & 0.0051 \\
\hline 5 & Bank Sinar Mas Tbk & BSIM & -0.0096 & 0.0053 \\
\hline 6 & Bank Bukopin Tbk & BBKP & -0.0103 & 0.0081 \\
\hline 7 & Bank QNB Indonesia Tbk & BKSW & -0.0136 & 0.0054 \\
\hline 8 & Bank MNC Internasional Tbk & BABP & -0.0153 & 0.0038 \\
\hline 9 & Bank Maybank Indonesia Tbk & BNII & -0.0231 & 0.0045 \\
\hline
\end{tabular}

Source: (Processed by author, 2018)

Based on the table, there are nine stocks that are not efficient, the investment decisions made on inefficient stocks / not good are to consider selling those Stocks.

Managerial Implications. In the CAPM method the relationship between expected returns and the risks of investment has a positive direction and is directly proportional. Investors will get risk asset if the expected rate of return is proportional to the risk (Ross, 2009) It is intended that the more expected rate of return, the greater the risk it will bear. The same with this research, the highest beta was found in Bank Mitra Niaga (NAGA) stocks, which amounted to 3,9804, had a positive relationship with the expected rate of return on the stocks of Bank Mitra Niaga (NAGA) which amounted to 0.0115 or $1.15 \%$. That company is the highest stock returns. The lowest beta is found in the stocks of Bank Yudha Bhakti Tbk company that is equal to -2.0213, and the expected rate of return of the 
company is the lowest expected rate of return of 0.0001 . The results of this study indicate that the banking sector shares have an efficient stock, because the average rate of return (actual return) is higher than the expected return (expected return). This is shown from the results of the study, namely there are 31 efficient shares of 40 shares in the banking sector.

\section{CONCLUSIONS}

Based on the analysis and discussion above that has been done in the previous chapter, the results of the research that has been done can be summarized as follows: (1) The results of the study show that there are 31 banking stocks with positive average return rates and 9 banking stocks with negative average returns. (2) Based on the results of the study there are 16 stocks that have $\beta>1,16$ shares that have $\beta<1$, and there are 8 stocks that have $\beta<0$. The average systematic risk of banking shares is 0.8030 , so that in general 40 shares of the company are made Research samples have a systematic risk that is not too high. (3) Based on the research there are 40 stocks with expected positive returns. With the highest rate of return is 0.0115 or $1.15 \%$, namely the shares of Bank Mitraniaga Tbk (NAGA). While the lowest rate of return is 0.0001 or equal to $0.01 \%$, namely the shares of Bank Yudha Bhakti (BBYB). (4) There are 31 stocks that are categorized as efficient shares and 9 shares of companies that are included in the category of inefficient shares of 40 shares of the company that were used as research samples. Efficient Stock is where the stock return rate $(\mathrm{Ri})$ is greater than the expected rate of return $\mathrm{E}(\mathrm{Ri})$.

Limitations. Based on research conducted by researchers, the limitations in this study are: (1) Research only uses banking companies listed on the Indonesia Stock Exchange (IDX). In order to study the Capital Asset Pricing Model well, the object of research can be added to other sectors, such as other financial sectors other than banking. (2) Research only uses the CAPM method in calculating risk and stock returns. Therefore, for the next researchers to be able to use the CAPM expansion method.

Suggestions. Based on the conclusions and limitations above, there are some suggestions that can be submitted are as follows:

For Investors. (1) If investors are interested in investing their capital in banking shares, investors should choose stocks that have an average rate of return on positive individual shares and include efficient stocks. (2) Investors should not invest in stocks that have an average rate of return on negative individual shares and inefficient stocks because the rate of return is smaller than the expected rate of return. (3) For investors who have risk likes (risk takers), it is better to choose stocks that have more than one beta. (4) Investors who tend to avoid risk should choose stocks that have less than one beta.

For Further Researchers. For further researchers, it is expected to conduct research on the development of the CAPM, such as the CCAPM (Consumption Capital Asset Pricing Model), LCAPM (Liquidity Adjusted Capital Asset Pricing Model), etc. The CAPM is the conceptual basis for the development of the CAPM. 


\section{REFERENCES}

Akram, F. M. (2017). Pengaruh Capital Asset Pricing Model Terhadap Harga Saham (Studi Pada Perusahaan - Perusahaan Sub Sektor Perbankan yang Listing di Bursa Efek Indonesia Periode 2014-2016). Jurnal Ilmu Administrasi Bisnis Vol.6 No.3.

Bodie and Marcus, 2. (2018). Investment 11th Edition. New York: Mc-Graw-Hill.

Elbannan, M. A. (2015). The Capital Asset Pricing Model : An Overview of the Theory. International Journal of Economics and Finance, Vol.7, No.1. 216-228.

Eugene F, B. (2017). Financial Management Theory and Practice.15th Edition. Singapore: South-Western Cengage Learning.

Husnan, S. (2015). Dasar-Dasar Teori Portofolio dan Analisis Sekuritas. Yogyakarta: UPPN STIM YKPN.

Jogiyanto. (2013). Teori Portofolio dan Analisis Investasi. : BPFE. Yogyakarta: BPFE.

Jones, C. P. (2013). Investments: Principles and Concepts 12th Edition. Singapore: Wiley: Asia.

Kasmir. (2014). Bank dan Lembaga Keuangan Lainnya. RajaGrafindo Persada.

Keown Arthur J., John D Martin., and J. William Petty. (2017). Foundations of Finance the Logic and Practice of Financial Management 9th Edition. Pearson.

Nasution, Y. S. (2015). Hypothesis Pasar Efisien/Efficient Market Hypothesis (Pasal Modal menurut Teori Fama dan Pandangan Islam). Jurnal Perspektif Ekonomi Darussalam Vol.1 No.1.

Putra, R. D. (2013). Analisis Pemilihan Investasi Saham dengan Menggunakan Metode Capital Asset Pricing Model (CAPM) dan Reward to Variability Ratio (RVAR) Sebagai Penentu Pengambilan Keputusan. Jurnal Administrasi Bisnis, Vol. 01. No.2.

Qamar, M. R., Rehman, S., and Shah, S. A. (2014). Applicability of Capital Assets Pricing Model (CAPM) on Pakistan Stock Markets. International Journal of Management and Business Research. Vol. 4. No.1.

Ross, S. A. (2009). Modern Financial Management, 9th Edition. Mc-Graw-Hill Companies.

Seftyanda, B. E., Darminto, dan Saifi, M. (2014). Analisis Metode Capital Asset Pricing Model (CAPM) Sebagai Dasar Pengambilan Keputusan Investasi Saham (Studi pada Seluruh Saham yang Terdaftar di BEI Periode 2010-2012). Jurnal Administrasi Bisnis Vol. 17 No.2.

Sekarwati, H. (2016). Penggunaan Capital Asset Pricing Model Dalam Menentukan Keputusan Berinvestasi Saham (Studi Pada Saham Indeks Kompas 100 di Bursa Efek Indonesia. Jurnal Manajemen Bisnis Indonesia (JMBI), Vol. 5, No.4.

Shaikh, S. A. (2013). Testing Capital Asset Pricing Model on KSE Stocks. . Journal of Managerial Sciences. Vol.7. No.2.

Tandelilin, E. (2010). Portofolio dan Investasi Teori dan Aplikasi. Yogyakarta: Kanisius.

Winarno, W. W. (2017). Analisis Ekonometrika dan Statistika dengan EViews. Yogyakarta: UPP STIM YKPN.

Yadnya, I. P. (2016). Penerapan Metode Capital Asset Pricing Model Sebagai Pertimbangan dalam Pengambilan Keputusan Investasi Saham. Jurnal Manajemen, Vol.5. No.12, 8079-8106.

Yulianti, R. (2014). Penerapan Metode CAPM (Capital Asset Pricing Model) Untuk Menentukan Keputusan Investasi. Jurnal Administrasi Bisnis, Vol.13, No.2. 1-9. 